\title{
The Importance of De Ritis Ratio in Patients with Bladder Cancer
}

\section{Mesane Kanseri Hastalarında De Ritis Oranının Önemi}

\author{
(D) Kasım Ertaş1, (D) Recep Eryılmaz¹, (D) Rahmi Aslan¹, (D) Murat Demir², (D Kerem Taken¹ \\ 1Van Yüzüncü Yıl University Faculty of Medicine, Department of Urology, Van, Turkey \\ ${ }^{2}$ University of Health Sciences Turkey, Van Training and Research Hospital, Clinic of Urology, Van, Turkey
}

\section{Abstract}

Objective: Numerous studies prove the relationship between serum aspartate transaminase/alanine transaminase (AST/ALT) ratio (De Ritis Ratio) and cancer cases. However, the results obtained by the researchers are controversial, and most scientific articles have different results. There are studies revealing the De Ritis Ratio relationship in urothelial carcinoma patients. Therefore, in this study, we aimed to reveal the relationship between De Ritis Ratio and bladder cancer.

Method: This study was carried out after getting the approval of our hospital's ethics committee dated 26/07/2018 and numbered 2018/12. One hundred seventy two patients who had bladder cancer and 68 healthy individuals in the control group were included in the study. It was evaluated whether there was a relationship between AST/ALT values and tumor stages and pathologies of these patients, and it was retrospectively investigated whether the De Ritis ratio differed between healthy and bladder cancer individuals.

Results: In this study, in which 240 individuals (including 172 patients and 68 controls) were evaluated, no statistical significance was observed between AST/ALT ratio and tumor stage, tumor pathology, ultrasound findings, and tumor size. However, a statistical difference was observed between the control group and the patient group in values of AST/ALT ratio. The De Ritis ratio (AST/ALT) in bladder cancer patients was higher than in the control group (mean: 1.18/0.91).

Conclusion: According to the findings of this study, AST/ALT ratio in bladder tumor patients differs compared to the control group. Therefore, it can be thought that the rate of De Ritis is a parameter that helps diagnosis and prognosis of these patients.

Keywords: Aspartate transaminase to alanine transaminase ratio, bladder cancer, De Ritis

\section{Öz}

Amaç: Çok sayıda çalışmada belirtildiği üzere, serum aspartat transaminaz/alanin transaminaz (AST/ALT) oranı (De Ritis Oranı) ile kanser olguları arasında ilişki bulunmaktadır. Ancak araştırmacıların elde ettikleri sonuçlar tartışmalıdır ve çoğu bilimsel makalede farklı sonuçlar bulunmaktadır. Ürotelyal karsinoma hastalarında De Ritis oranının arttığını gösteren araştırmalar mevcuttur. Bu çalışmada diğer araştırmalarla benzer bir biçimde De Ritis oranı ile mesane kanseri arasındaki ilişki araştırılmıştır.

Yöntem: Bu çalışma hastanemizin 20/07/2018 tarihli ve 2018/12 belge no'lu etik kurulu onayı müsaadesince gerçekleştirilmiştir. Çalışmaya mesane kanserinden ameliyat edilen 172 hasta ve 68 sağlıklı bireyden oluşan kontrol grubu dahil edilmiştir. Bu hastaların AST/ALT değerleri ile tümör evreleri, patolojileri arasında bir ilişki olup olmadığı değerlendirilmiş, ayrıca De Ritis oranının sağlıklı ve hasta bireyler arasında farklılık gösterip göstermediği retrospektif olarak araştırılmıştır.

Bulgular: Yüz yetmiş iki hasta ve 68 kontrol grubu olmak üzere toplamda 240 kişinin değerlendirildiği bu çalışmada, AST/ALT oranı ile tümör evresi, tümör patolojisi, ultrason bulguları, tümör boyutu arasında herhangi bir istatistiksel anlamlılık gözlenmemiş, buna karşın kontrol grubu ile mesane kanseri hastaları arasında AST/ALT oranı bakımından istatistiksel olarak farklılık gözlenmiştir. Mesane kanseri hastalarında De Ritis oranı (AST/ ALT) kontrol grubuna göre yüksek bulunmuştur (ortalama: 1,18/0,91).

Sonuç: Bu çalışmanın bulgularına göre, mesane tümörü hastalarında AST/ALT oranı kontrol grubu ile karşılaştıııldığında farklılık göstermektedir. Bu nedenle, De Ritis oranının bu hastaların değerlendirilmesinde teşhise ve hastalığın seyrine yardımcı bir parametre olduğunu düşünülebilir.

Anahtar kelimeler: Aspartat transaminaz/alanin transaminaz oranı, De Ritis, mesane kanseri

Address for Correspondence: Kasım Ertaş, Van Yüzüncü Yıl University Faculty of Medicine, Department of Urology, Van, Turkey

E-mail: drkasim_ertas@hotmail.com ORCID: orcid.org/0000-0003-4300-1399 Received: 10.03.2020 Accepted: 06.07.2020

Cite this article as: Ertaş K, Eryılmaz R, Aslan R, Demir M, Taken K. The Importance of De Ritis Ratio in Patients with Bladder Cancer. Bagcilar Med Bull 2020;5(3):69-74

${ }^{\circ}$ Copyright 2020 by the Health Sciences University Turkey, Bagcilar Training and Research Hospital Bagcilar Medical Bulletin published by Galenos Publishing House. 


\section{Introduction}

Urothelial carcinomas typically occur in the human urinary system. Malignancies included in the group of urothelial carcinomas involve the kidneys, bladder and auxiliary organs. These cancers are most frequently in the bladder cancer (BC), ureters, and urethra, respectively. BC is the second most common type of cancer in the genitourinary system.

Generally more than $90 \%$ of bladder tumors are urothelial carcinomas, which differs from normal urothelium in that it presents more epithelial layers, changes in cellular maturation, prominent nucleoli and more mitosis. The macroscopic presentation of urothelial carcinoma can be papillary (more frequent), sessile, infiltrative (malignant characteristic), nodular, or mixed carcinoma in situ (CIS). In the examination of cystoscopy, CIS may appear as an area of hyperemia and flat, or often go unnoticed. It consists of a tumor of poorly differentiated urothelial cells and is confined to the epithelium, which can cause symptoms of polyuria, dysuria and urinary urgency. Ultrasonography and other imaging methods are unable to identify CIS because of its flat appearance.

Bladder cancer is usually operated with transurethral tumor resection, a modern method and a minimally invasive surgical procedure, if no other medical condition is involved. However, pelvic lymph node dissection (PLND) and radical cystectomy (RC) have been used as traditional surgery methods for local muscle invasive BC (MIBC). $\mathrm{RC}$ with PLND is sometimes used to treat non-muscular invasive BC (NMIBC), including Bacille Calmette-Guerin resistant cases and high grade tumors. In this cancer, the prognosis of NMIBC patients is generally good, if the malignant cells increase and the disease does not occur in MIBC. However, in most NMIBC patients, approximately $30 \%$ of them have MIBC unfortunately. As a result, half of the operated patients have cancer again within 2 years. The 3 -year survival rate in the operated patients is less than $50 \%$ (1). However, even if RC is performed, the prognosis of the disease is poor. Cancer recurrence occurs in more than $30 \%$ of patients after RC (2) and BC, and this cancer is the 13th most common cause of cancer-related deaths (3).

Transurethral resection of bladder tumor represents the first step in the diagnostic and treatment process of BC (4). As much as $75 \%$ of newly diagnosed BCs are diagnosed at the stage of NMIBC disease, i.e. limited to mucosa (Ta and CIS) or to the lamina propria (T1) (5). However, eligible patients are difficult to identify due to the poor prognostic value of the current clinical staging system, resulting in inadequate use (6). Therefore, a preoperative prognostic factor that can be stratified sufficiently is required for optimal preoperative treatment of patients.

Various biomarkers for early diagnosis and prognosis prediction of BC, such as Engrailed-2 protein, bladder tumor antigen, methylation biomarkers, cytokeratin 20, Nuclear matrix protein 22, soluble FAS [the FAS belongs to the tumor necrosis factor receptor superfamily], and fibroblast growth factor receptor have been discussed. There are also many mRNA-based biomarker tests, such as the Cx bladder monitor, XPERT BC, and BC test $(7,8)$.

In 1957, the serum activity rate of aspartate transaminase (AST) and alanine transaminase (ALT) was first discovered by Fernande De Ritis and was then referred to as the De Ritis ratio (AST/ALT) (9). ALT and AST enzymes are found in the red blood cells, brain, kidney, heart, skeletal muscle, but are found in the liver mostly. Because they are found in most vital organs, they are also used as an indicator of many diseases $(10,11)$. Cancer and non-cancerous tissues have been shown to be important prognostics because they produce these enzymes in many malignant tumors. These include multiple myeloma, colon, pancreatic, renal cell carcinoma (RCC) and upper system urothelial cancer $(12,13)$. It is also assumed that the De Ritis ratio is associated with increased anaerobic glycolysis, a process known as the Warburg effect. In this study, we suggest that for all these reasons, the De Ritis ratio may play a diagnostic role in $\mathrm{BC}$, because $\mathrm{BC}$ has been reported to be associated with glucose metabolism $(14,15)$.

\section{Materials and Methods}

In this retrospective analysis, medical records of 172 patients who applied with BC and who underwent transurethral resection-bladder tumor in our clinic between 2016 and 2019 and 78 healthy controls were examined. This study was carried out after getting the approval of our hospital's ethics committee dated 26/07/2018 and numbered 2018/12. The study was approved by the local ethics committee and Informed consent was obtained from appropriate patients. The mean age of the patients (mean \pm standard deviation) was $62.18 \pm 14.04$ years and the mean age of the control group was $61.79 \pm 11.73$ years. The ages of the patients varied between 18 and 92 years, the ages of the control group were between 30 and 85 years. 13\% of patients were female and $87 \%$ were male (Table 1). Plasma AST and ALT levels were analyzed by standard clinical methodology within 7 days 
before surgery. Pathological features included tumor size, tumor stage, and deep tissue invasion.

\section{Statistical Analysis}

Data were analyzed by using Statistical Package for the Social Sciences software package version 20 (SPSS Inc., Chicago, IL, USA). The Kolmogorov-Smirnov and ShapiroWilk tests were used to determine whether the data showed normal distribution. In the study, power analysis was performed with G-Power 3.1.9.2 software to calculate the number of samples. Considering the Kolmogorov-Smirnov and Shapiro-Wilk analyses, the Mann-Whitney U tests were applied to determine whether the parameters that did not show normal distribution differed between the groups. The average and standard deviations of these test parameters are given in results section. The Kruskal-Wallis test, one of the non-parametric tests, was used to determine whether the AST/ALT values of BC patients changed according to the tumor stages, pathologies, and ultrasound (USG) findings. In the study, discriminant analysis was performed to determine whether $\mathrm{BC}$ patients differed in terms of their tumor stages and AST/ALT values. Another purpose of this analysis is to detect the group that belongs to any of the groups, but which group is not known, with the least error. It is possible to sum up the purposes of discriminant analysis in two groups: To determine the discriminant functions and to determine the discriminant variables that affect the inter-group discrimination through these functions.

\section{Results}

Of the 172 patients included in the study, 151 were male and 21 were female. Forty four of the individuals in the control group were male and 24 were female. The pathological stages (tumor grade) of these patients were distributed as follows, $66.6 \%(n=115)$ of the patients were at the low grade stage, $33.4 \%(n=57)$ at the high grade stage. When BC patients were classified according to their $\mathrm{T}$ stage, it was found that $42 \%$ $(n=73)$ of these patients were at the T0 stage, $36 \%(n=36)$ were at the T1 stage, $22 \%(n=37)$ were at the T2 stage, and there

\begin{tabular}{llllll}
\hline $\begin{array}{l}\text { Table 1. Demographic properties of patient and control } \\
\text { groups }\end{array}$ & $\begin{array}{l}\text { Average } \\
\text { value }\end{array}$ & $\begin{array}{l}\text { Standard } \\
\text { deviation }\end{array}$ & $\begin{array}{l}\text { Min-max } \\
\text { age }\end{array}$ & $\begin{array}{l}\% \\
\text { Male }\end{array}$ & $\begin{array}{l}\% \\
\text { Female }\end{array}$ \\
\hline $\begin{array}{l}\text { Patients' } \\
\text { age }\end{array}$ & 62.18 & 14.04 & $18-92$ & 87 & 13 \\
$\begin{array}{l}\text { Control } \\
\text { group's } \\
\text { age }\end{array}$ & 61.79 & 11.73 & $30-85$ & 84 & 16 \\
\hline
\end{tabular}

Min: Minimum, Max: Maximum were no patients in the T3 and T4 stages. Patients' serum AST mean and standard deviation values were $20.91 \pm 9.02 \mathrm{IU} / \mathrm{L}$, respectively. The minimum AST value measured in the serum of patients was $7 \mathrm{IU} / \mathrm{L}$, the maximum AST value was $65 \mathrm{IU} / \mathrm{L}$. The mean and standard deviation value of patients' ALT value was $19.67 \pm 10.23 \mathrm{IU} / \mathrm{L}$, respectively. The mean and standard deviation value of AST was $15.87 \pm 4.27 \mathrm{IU} / \mathrm{L}$ in the serum of the control group. The mean and standard deviation value for ALT was $14.83 \pm 7.90 \mathrm{IU} / \mathrm{L}$ in patients.

The results of the Shapiro-Wilk test and KolmogorovSmirnov tests were applied to determine the normal distribution $(\mathrm{p}<0.005)$. Accordingly, no parameters of BC patients used in the study showed normal distribution.

The AST, ALT and "De Ritis" values were obtained from AST/ ALT ratio and a statistically significant difference could not be detected compared to tumor stage, pathological stage, multifocal classification values with the Kruskal-Wallis test. This means that there was no difference in terms of ALT, AST and De Ritis ratio among the T0, T1 and T2 classes of the Tumor Stage parameter, and no difference between tumor grade classes of low grade and high grade according to AST, ALT and De Ritis ratios.

The relationship between USG and length values and ALT value was significant (Table 2).

According to the discriminant function analysis results, the test parameter separating the patient and control groups was AST $(\mathrm{p}=0.000)$. ALT and De Ritis ratio were not effective in separating these two groups (Table 3 ).

\begin{tabular}{lllll} 
Table 2. Kruskal-Wallis test results & & \\
& & AST & ALT & De Ritis \\
\hline \multirow{4}{*}{ Tumor grade } & Chi-square & 2.119 & 2.606 & 4.025 \\
& Df & 2 & 2 & 2 \\
& Asymp. sig. & 0.347 & 0.272 & 0.134 \\
\multirow{5}{*}{ T stage } & Chi-square & 3.741 & 4.342 & 4.064 \\
& Df & 2 & 2 & 2 \\
\multirow{4}{*}{ Multifocal } & Asymp. sig. & 0.154 & 0.114 & 0.131 \\
& Chi-square & 0.281 & 1.98 & 1.879 \\
& Df & 2 & 2 & 2 \\
& Asymp. sig. & 0.869 & 0.372 & 0.391 \\
Length & Chi-square & 1.959 & 13.361 & 7.43 \\
& Df & 3 & 3 & 3 \\
& Asymp. sig. & 0.581 & 0.004 & 0.059 \\
& Chi-square & 11.894 & 13.301 & 3.277 \\
USG & Df & 3 & 3 & 3 \\
& Asymp. sig. & 0.008 & 0.004 & 0.351 \\
\hline
\end{tabular}

AST: Aspartate transaminase, ALT: Alanine transaminase, USG: Ultrasound 
When the De Ritis ratios of the patient and control groups were compared with the Mann-Whitney U test, there was a significant difference between the patient and the control groups (Table 4).

The mean and standard deviation values of De Ritis ratios of the patient and control groups were clearly different from each other. De Ritis rates were higher in the patient group than in the control group (Table 5).

\section{Discussion}

Aspartate transaminase is an enzyme found in the body cells, heart and liver, and to a lesser extent in the kidneys and muscles. ALT, on the other hand, is an enzyme mostly found in the liver and in smaller amounts in the kidneys, heart and muscles. In healthy individuals, AST and ALT are low in blood. Italian, Internal Medicine specialist medical doctor and also a great philanthropist, Fernande De Ritis showed in 1957 that amino transaminases could be used to distinguish between viral hepatitis and alcohol-induced hepatitis. This index, which Fernande De Ritis defined as the AST/ALT ratio, has now passed into the medical literature as the "De Ritis Ratio" (7). These transaminase enzymes, which are strongly involved in cellular metabolism and cancer cell cycle, are indicators that can be easily measured in the blood (16). Scientific studies have stated that AST/ ALT ratio is a prognostic factor, as listed as follows; Stocken et al. (15) in pancreatic cancer, Bezan et al. (14) in non- metastatic RCC, Nishikawa et al. (16) De Ritis ratio as a significant predictor of recurrence-free survival in patients with upper urinary tract urothelial carcinoma following nephroureterectomy, Rawson and Peto (17) in lung cancer, Tan et al. (18) in distal cholangiocarcinoma $(19,20)$. According to the hypothesis suggested by Nobel laureate famous biochemist and medical doctor Otto Heinrich Warburg, which was referred to as "Warburg effect", it is assumed that cancer, malignant growth, and tumor growth are due to the fact that tumor cells produce energy as a result of the breakdown of glucose without oxygen (glycolysis). This is in contrast to healthy cells that produce energy mainly from the oxidative breakdown of pyruvate. Pyruvate is a final product of glycolysis and oxidized in mitochondria. Therefore, according to Warburg, carcinogenesis is due to a decrease in mitochondrial oxidative phosphorylation. Warburg assumed that the main difference between normal and cancerous cells was the ratio of glycolysis to oxidative phosphorylation (19). Ha et al. (20) found the relationship between De Ritis ratio and clinicopathological findings in their studies. In their study, they retrospectively investigated the clinicopathological data of 118 patients with metastatic urothelial BC after RC. and found that the high rate of De Ritis in urothelial BC patients, which were receiving RC therapy, was significantly associated with the rate of De Ritis with poor prognosis. They stated that this rate might further increase the predictive accuracy for prognosis in BC (20). In the findings obtained in this study,

\begin{tabular}{|c|c|c|c|c|c|c|c|c|c|}
\hline \multirow[b]{2}{*}{ Step } & \multirow[b]{2}{*}{ Entered } & \multicolumn{8}{|c|}{ Wilks' Lambda } \\
\hline & & Statistic & df1 & df2 & df3 & \multicolumn{4}{|l|}{ Exact $\mathrm{F}$} \\
\hline 1 & AST & 0.939 & 1 & 1 & 219.000 & 14.336 & 1 & 219.000 & 0.000 \\
\hline
\end{tabular}

(At each step, the variable that minimizes the overall Wilks' Lambda is entered, Maximum number of steps is 6. Minimum partial $\mathrm{F}$ to enter is 3.84. Maximum partial $\mathrm{F}$ to remove is 2.71. F level, tolerance, or VIN insufficient for further computation). AST: Aspartate transaminase

Table 4. Mann-Whitney $U$ test results of De Ritis ratio in the patient and control groups

\begin{tabular}{lc} 
& De Ritis \\
\hline Mann-Whitney U & 2275.5 \\
Wilcoxon W & 3095.5 \\
Z & -3.333 \\
Asymp. Sig. (2-tailed) & 0.001 \\
\hline
\end{tabular}

Table 5. Descriptive statistical results of De Ritis ratio in the patient and control groups

\begin{tabular}{|c|c|c|c|c|c|c|}
\hline \multirow{3}{*}{ De Ritis ratio } & \multirow{3}{*}{ Patients } & Mean & 1.181773 & \multirow{3}{*}{ Control } & Mean & 0.914028 \\
\hline & & Standard deviation & 0.407367 & & Standard deviation & 0.342533 \\
\hline & & Minimum & 0.466667 & & Minimum & 0.416667 \\
\hline
\end{tabular}


De Ritis ratio differs positively in BC patients, especially in patients with advanced tumor stage, compared to the control group.

\section{Conclusion}

According to our study results, De Ritis ratio was higher in BC patients than in the control group. In addition, as a result of the statistical analysis, the patient and control groups were separated from each other in terms of De Ritis ratio. According to this result, De Ritis ratio can provide information about the diagnosis of $\mathrm{BC}$ patients and the course of the disease. De Ritis ratio did not cause a significant difference between tumor stages, tumor sizes and pathological stages. This is because the tumor stages of patients included in this study were close to each other. The tumor stages of patients included in this study were $\mathrm{T} 0, \mathrm{~T} 1$, and $\mathrm{T} 2$. Among these patients, there were no patients in the $\mathrm{T} 3$ and $\mathrm{T} 4$. The situation was the same in pathological stages. According to the patients' pathologies, bladder tumors were superficial and did not cross the basement membrane and retain the muscle layer. Tumor diameters measured before surgery and preoperative USG measurements were compatible with each other. The results of this study and the studies of Ha et al. (20), Nishikawa et al. (16) and Bezan et al. (14) are parallel to each other. In future studies to be carried out for the same purpose, more reliable results can be obtained if the following are considered, firstly, liver functions of the patient and control groups should be equivalent, viral hepatitis, alcohol use, human herpes viruses (HSV, VZV, EBV, CMV), Coxsacki B, Adenovirus, Measles, Rubella, Mumps, non A-E Hepatitis Viruses (TTV and SEN-V), Hepatitis A, B, C, D, E, G, metabolic diseases, Alpha-1 Antitrypsin Deficiency, Hemochromatosis and Systemic diseases can cause AST/ALT increase.

\section{Ethics}

Ethics Committee Approval: This study was carried out after getting the approval of our hospital's ethics committee dated 26/07/2018 and numbered 2018/12.

Informed Consent: Informed consent was obtained from appropriate patients.

Peer-review: Externally peer-reviewed.

\section{Authorship Contributions}

Concept: K.E., Design: R.A., Data Collection or Processing: M.D., Analysis or Interpretation: R.E., Literature Search: K.T., Writing: K.E.
Conflict of Interest: No conflict of interest was declared by the authors.

Financial Disclosure: The authors declared that this study has received no financial support.

\section{References}

1. Ouzzane A, Colin P, Xylinas E, Pignot G, Ariana MM, Saint F, et al. Ureteral and multifocal tumours have worse prognosis than renal pelvic tumours in urothelial carcinoma of the upper urinary tract treated by nephroureterectomy. Eur Urol 2011;60(6):1258-1265.

2. Murphy DM, Zincke H, Furlow WL. Management of high grade transitional cell cancer of the upper urinary tract. J Urol 1981;125(1):25-29.

3. Sternberg CN, Bellmunt J, Sonpavde G, Siefker-Radtke AO, Stadler WM, Bajorin DJ, et al. ICUD-EAU International Consultation on Bladder Cancer 2012: chemotherapy for urothelial carcinomaneoadjuvant and adjuvant settings. Eur Urol 2013;63(1):58-66.

4. Necchi A, Anichini A, Raggi D, Briganti A, Massa S, Luciano R, et al. Pembrolizumab as neoadjuvant therapy before radical cystectomy in patients with muscle-invasive urothelial bladder carcinoma (PURE-01): an open-label, single-arm, phase II study. J Clin Oncol 2018;36(34):3353-3360.

5. Madersbacher S, Hochreiter W, Burkhard F, Thalmann G, Danuser $\mathrm{H}$, Markwalder R, et al. Radical cystectomy for bladder cancer today-a homogeneous series without neoadjuvant therapy. J Clin Oncol 2003;21(4):690-696.

6. Stewart GD, Bariol SV, Grigor KM, Tolley DA, McNeill SA. A comparison of the pathology of transitional cell carcinoma of the bladder and upper urinary tract. BJU Int 2005;95(6):791-793.

7. Suer E, Hamidi N, Gokce MI, Gulpinar O, Turkolmez K, Beduk Y, et al. Significance of second transurethral resection on patient outcomes in muscle-invasive bladder cancer patients treated with bladder-preserving multimodal therapy. World J Urol 2016;34(6):847-851.

8. Morgan R, Bryan RT, Javed S, Launchbury F, Zeegers MP, Cheng KK, et al. Expression of Engrailed-2 (EN2) protein in bladder cancer and its potential utility as a urinary diagnostic biomarker. Eur J Cancer 2013;49(9):2214-2222.

9. Lee H, Choi YH, Sung HH, Han DH, Jeon HG, Jeong CB, et al. De Ritis Ratio (AST/ALT) as a Significant Prognostic Factor in Patients With Upper Tract Urothelial Cancer Treated With Surgery. Clin Genitourin Cancer 2017;15(3):e379-e385.

10. Lin CS, Chang CS, Yang SS, Yeh HZ, Lin CW. Retrospective evaluation of sérum markers APRI and AST/ALT for assessing liver fibrosis and cirrhosis in chronic hepatitis B and C patients with hepatocellular carcinoma. Intern Med 2008;47(7):569-575.

11. Yun SJ, Jo SW, Ha YS, Lee OJ, Kim WT, Kim YJ, et al. PFKFB4 as a prognostic marker in non-muscle-invasive bladder cancer. Urol Oncol 2012;30(6):893-899.

12. Chang SG, Lee JH, Hong DH, Lee HL, Chai SE, Hoffman RM. Comparison of glucose-consumption and thymidineincorporation endpoints in histocultured human superficial bladder tumors. Anticancer Res 1994;14(1A):77-83.

13. Stein JP, Quek ML, Skinner DG. Lymphadenectomy for invasive bladder cancer. II. technical aspects and prognostic factors. BJU Int 2006;97(2):232-237. 
14. Bezan A, Mrsic E, Krieger D, Stojakovic T, Pummer K, Zigeuner R, et al. The preoperative AST/ALT (De Ritis) ratio represents a poor prognostic factor in a cohort of patients with nonmetastatic renal cell carcinoma. J Urol 2015;194(1):30-35.

15. Stocken DD, Hassan AB, Altman DG, Billingham LJ, Bramhall SR, Johnson PJ, et al. Modelling prognostic factors in advanced pancreatic cancer. Br J Cancer 2008;99(6):883-893.

16. Nishikawa M, Miyake H, Fujisawa M. De Ritis (aspartate transaminase/alanine transaminase) ratio as a significant predictor of recurrence-free survival in patients with upper urinary tract urothelial carcinoma following nephroureterectomy. Urol Oncol 2016;34(9):417.e419-e415.

17. Rawson NS, Peto J. An overview of prognostic factors in small cell lung cancer. A report from the Subcommittee for the Management of lung Cancer of the United Kingdom coordinating committee on Cancer research. Br J Cancer 1990;61(4):597-604.

18. Tan X, Xiao K, Liu W, Chang S, Zhang T, Tang H. Prognostic factors of distal cholangiocarcinoma after curative surgery: a series of 84 cases. Hepatogastroenterology 2013;60(128):1892-1895.

19. Warburg O. On theorigin of cancercells. Science 1956;123(3191):309314.

20. Ha YS, Kim SW, Chun SY, Chung JW, Choi SH, Lee JN, et al. Association between De Ritis ratio (aspartate aminotransferase/ alanine aminotransferase) and oncological outcomes in bladder cancer patients after radical cystectomy. BMC Urol 2019;19(1):10. 